\title{
Element Concentration in the Prepared and Commercial Feed as Well Their Status in the Breast Muscle of Chicken after Prolonged Feeding
}

\author{
Jayanta Kumar Goswami ${ }^{1}$, Satya Sarmah ${ }^{2}$, Dhirendra K. Sharma ${ }^{{ }^{*}}$ \\ ${ }^{1}$ Bioinformatics Centre, Department of Zoology, Gauhati University, Guwahati, India; ${ }^{2}$ Department of Biochemistry, College of Vet- \\ erinary Sciences, Guwahati, India. \\ Email: *dksguniv@gmail.com
}

Received July 27 $7^{\text {th }}$ 2013; revised August $27^{\text {th }}, 2013$; accepted September $5^{\text {th }}, 2013$

Copyright (C) 2013 Jayanta Kumar Goswami et al. This is an open access article distributed under the Creative Commons Attribution License, which permits unrestricted use, distribution, and reproduction in any medium, provided the original work is properly cited.

\begin{abstract}
Quality poultry meat depends upon the feed and as such there are many commercially available feeds. However, their composition and standard by and large throughout the year may not remain same due to obvious reasons. Moreover, there is no mention of locally produced feed particularly in the north eastern part of India. The major objective of this study was to prepare mesh feed E1 with the available ingredients as well as their effect were compared with that of the two commercially available feed Amrit and Godrej (E2 and E3) in terms of Crude protein, fats and element composition. The findings showed that the protein content $(240 \mathrm{~g} / \mathrm{kg})$ and fats $(105 \mathrm{~g} / \mathrm{kg})$ in the breast muscle of female was higher in the E3 received against the broiler chicken received local feed. Element analysis of the E1, E2 and E3 depicted significantly higher value of $\mathrm{Ca}, \mathrm{K}, \mathrm{Cu} \mathrm{Zn}$ and Se against the commercial feed. Other elements like Mg, $\mathrm{Na}, \mathrm{Fe}, \mathrm{P}$, and $\mathrm{Mn}$ showed no variation while compared E1, E2 and E3 together. Thus the present findings suggest that the local feed E1 could be accepted at per with that of the commercial feed for poultry.
\end{abstract}

Keywords: Mesh Food; Elements; Comparison; Chicken Breast Muscle

\section{Introduction}

Poultry is a rapidly growing industry, and being a rich source of protein and micro nutrient, contributes a useful component to human diet. The modern broiler has been generally selected for rapid gains and efficient utilization of nutrients. Broilers are capable of thriving on widely varied types of diets, but do best on diets composed of low-fiber grains and highly digestible protein sources. Nutritional quality of broiler's meet always depends on proteins, free amino acids, minerals and vitamins. Lazar [1] was of the view that the ideal quantum of certain minerals in poultry meet should be for $\mathrm{K}(0.4 \%)$, $\mathrm{P}(0.2 \%)$, $\mathrm{Na}(0.09 \%)$ etc.

Significantly, the quality of the meat mostly depends upon the types of feed. Generally proteins are the major constituents of the poultry meat [2] along with the mineral constituents. In broiler nutrition, the concept of ideal protein has been widely accepted with growth rate and

${ }^{*}$ Corresponding author. breast meat yield increases with balanced protein intake. It has also consistently been shown that if an adequate quantity of essential nutrients is maintained in relation to metabolic energy (ME), increasing concentrations of energy for broilers result in a more rapid weight gain and an improvement in feed conversion [3].

On the other hand differences in the quantum of the nutrients in terms of male and female, particularly in the breast muscle of female, which is finer and more tender [4] attracts significance. In addition, many of the stress, including the dietary stress stimuli could act in the homeostasis which in turn may cause loss of macro and microelements, deficiency of which in meat may affect the quality. Good broiler growth rates will be achieved if the daily nutritional requirement of the bird is met. The ability of the bird to achieve its daily nutritional requirement will, in part, depend upon the nutrient composition of the diet and what the bird actually responds to feed is as nutrient intake. For a good broiler growth and efficient nutrient utilization it is, therefore, vital to ensure that a 
good feed intake is achieved. Feed intake can be significantly affected by feed form. A poor feed form will inhibit feed intake and have a negative impact on growth rate [5].

The cost, easy availability and nutritional quality of feed coupled with genetically potent feed efficient stocks to produce safe food from poultry are the need of time [6]. The relationship between feed ingredient and animal product output is both direct and obvious, and the conventional feed stuffs are very expensive and scarce [7]. The commonly used feedstuffs in poultry diet i.e. maize, soybean meal, groundnut meal, fish meal etc. which mainly depends on their nutritive value as well as absence of any incriminating factor.

Moreover, the available quantum of macro and microelements either in commercial feed or in indigenously prepared feed is data deficient. Hence, an attempt has been made to determine the contents of $\mathrm{Ca}, \mathrm{Mg}, \mathrm{P}, \mathrm{Na}, \mathrm{K}$, $\mathrm{Fe}, \mathrm{Cu}, \mathrm{Zn}, \mathrm{Mn}$, in the commercially available feed, indigenously prepared feed as well as their accumulation in the breast muscle of broiler chicken.

\section{Materials and Method}

\subsection{Experimental Birds}

300 VENCOBB commercial broiler chicks of uniform weight (day-old) were procured from a commercial hatchery. Chicks were weighed individually and wing bended. Chicks were randomly allotted according to nearest body weight to three experimental treatments groups. Each group was subdivided into two replicates of 50 chicks.

\subsection{Experimental Ration}

Three experimental Rations were considered to evaluate three types of rations, viz. prepared ration with conventional ingredients (E1) and two rations procured from the market Amrit (E2) an Godrej (E3) respectively.

Eighty numbers of samples were collected from sales and display centre of feed mills mainly from Jorhat, Golaghat, Sonitpur and Kamrup (urban) districts of Assam, India. These compounded feeds available in Assam were collected randomly for chemical analysis. While collecting the samples, at least three samples from each company were collected and pooled sample was analyzed. These two compounded feeds were in the form of crumbles and pellets.

The control diet (Ration-1) was formulated for prestarter (0 - 1 week), starter (1 - 4 weeks) and finisher (4 6 weeks) separately with conventional ingredients. Prestarter, starter and finisher rations were calculated for crude proteins (CP) and metabolic energy (ME) values. All the ingredients were obtained from local market.

\subsection{Physical and Chemical Composition of the Prepared Rations of Broiler}

As per standard protocol the control (Ration 1) was prepared as Pre-starter, Starter and broiler Finisher for the experimental birds [8]. The prepared and their analysis are presented in the Tables 1, 2 and 3.

Table 1. Physical and calculated chemical composition of prestarter feed. ME: Metabolic energy, CP: Crude proteins.

\begin{tabular}{|c|c|c|c|c|c|}
\hline Ingredients & Parts /100kg & ME/kg & MEKcal/kg & CP\% & $\mathbf{C P}$ \\
\hline $\begin{array}{l}\text { Maize } \\
\text { (energy source) }\end{array}$ & 50 & 3430 & 1715 & 8.7 & 4.4 \\
\hline $\begin{array}{l}\text { Groundnut cake } \\
\text { (protein source) }\end{array}$ & 15 & 2790 & 419 & 39.5 & 5.9 \\
\hline $\begin{array}{l}\text { Soya bean } \\
\text { (protein source) }\end{array}$ & 26 & 3510 & 913 & 41.7 & 10.8 \\
\hline $\begin{array}{l}\text { Fish Meal } \\
\text { (protein source) }\end{array}$ & 5 & 2100 & 105 & 40 & 2.0 \\
\hline Oyster shell grit & 1 & 0 & 0 & 0 & 0 \\
\hline $\begin{array}{l}\text { Dicalcium } \\
\text { Phosphate }\end{array}$ & 1.1 & 0 & 0 & 0 & 0 \\
\hline Methionine & 0.25 & 0 & 0 & 0 & 0 \\
\hline Lysine & 0.2 & 0 & 0 & 0 & 0 \\
\hline Trace Mineral & 0.5 & 0 & 0 & 0 & 0 \\
\hline Salt & 0.25 & 0 & 0 & 0 & 0 \\
\hline Probiotic & 0.01 & 0 & 0 & 0 & 0 \\
\hline $\begin{array}{l}\text { Choline } \\
\text { chloride }\end{array}$ & 0.1 & 0 & 0 & 0 & 0 \\
\hline $\begin{array}{l}\text { Livol } \\
\text { (liver tonic) }\end{array}$ & 0.5 & 0 & 0 & 0 & 0 \\
\hline $\begin{array}{l}\text { Toxin binder } \\
\text { (antifungal) }\end{array}$ & 0.1 & 0 & 0 & 0 & 0 \\
\hline \multirow[t]{2}{*}{$\begin{array}{l}\text { Juricox } \\
\text { (coccidiostate) }\end{array}$} & 0.05 & 0 & 0 & 0 & 0 \\
\hline & & & 3151.1 & & 23.1 \\
\hline
\end{tabular}

Table 2. Physical and calculated chemical composition of starter feed. ME: Metabolic energy, CP: Crude proteins.

\begin{tabular}{|c|c|c|c|c|c|}
\hline Ingredients & Parts/100kg & ME/kg & ME (Kcal/kg) & CP\% & $\mathbf{C P}$ \\
\hline Maize & 51 & 3430 & 1749 & 8.7 & 4.4 \\
\hline $\begin{array}{l}\text { Groundnut cake } \\
\text { (protein source) }\end{array}$ & 16 & 2790 & 446 & 39.5 & 6.32 \\
\hline $\begin{array}{l}\text { Soya bean } \\
\text { (protein source) }\end{array}$ & 24 & 3510 & 842 & 41.7 & 10 \\
\hline $\begin{array}{l}\text { Fish Meal } \\
\text { (protein source) }\end{array}$ & 5.0 & 2100 & 105 & 40 & 2.0 \\
\hline Oyster shell grit & 1.0 & 0 & 0 & 0 & 0 \\
\hline $\begin{array}{l}\text { Dicalcium } \\
\text { Phosphate }\end{array}$ & 1.1 & 0 & 0 & 0 & 0 \\
\hline Methionine & 0.25 & 0 & 0 & 0 & 0 \\
\hline Lysine & 0.2 & 0 & 0 & 0 & 0 \\
\hline Trace Mineral & 0.5 & 0 & 0 & 0 & 0 \\
\hline Salt & 0.25 & 0 & 0 & 0 & 0 \\
\hline Probiotic & 0.01 & 0 & 0 & 0 & 0 \\
\hline $\begin{array}{l}\text { Choline } \\
\text { chloride }\end{array}$ & 0.1 & 0 & 0 & 0 & 0 \\
\hline $\begin{array}{l}\text { Livol } \\
\text { (liver tonic) }\end{array}$ & 0.5 & 0 & 0 & 0 & 0 \\
\hline $\begin{array}{l}\text { Toxin binder } \\
\text { (antifungal) }\end{array}$ & 0.1 & 0 & 0 & 0 & 0 \\
\hline \multirow[t]{2}{*}{$\begin{array}{l}\text { Juricox } \\
\text { (coccidiostate) }\end{array}$} & 0.05 & 0 & 0 & 0 & 0 \\
\hline & & & 3142 & & 22.72 \\
\hline
\end{tabular}


Table 3. Physical and calculated chemical composition of finisher feed. ME: Metabolic energy, CP: Crude proteins.

\begin{tabular}{cccccc}
\hline Ingredients & $\begin{array}{c}\text { Parts/ } \\
\mathbf{1 0 0 k g}\end{array}$ & ME/kg & $\begin{array}{c}\text { ME } \\
\text { Kcal/kg }\end{array}$ & $\mathbf{C P \%}$ & $\begin{array}{c}\text { CP } \\
\text { (total) }\end{array}$ \\
\hline Maize & 55 & 3430 & 1887 & 8.7 & 4.8 \\
Groundnut cake & 15 & 2790 & 419 & 39.5 & 5.9 \\
Soya bean & 21 & 3510 & 737 & 41.7 & 8.8 \\
DORB & 5 & 2100 & 105 & 12.9 & 0.6 \\
OSG & 1 & 0 & 0 & 0 & 0 \\
DCP & 1.1 & 0 & 0 & 0 & 0 \\
Salt & 0.5 & 0 & 0 & 0 & 0 \\
Trace mineral & 0.25 & 0 & 0 & 0 & 0 \\
Methionine & 0.25 & 0 & 0 & 0 & 0 \\
Lysine & 0.2 & 0 & 0 & 0 & 0 \\
Choline chloride & 0.1 & 0 & 0 & 0 & 0 \\
Livol & 0.5 & 0 & 0 & 0 & 0 \\
Toxin binder & 0.05 & 0 & 0 & 0 & 0 \\
Juricox & 0.05 & 0 & 0 & 0 & 0 \\
& & & 3147 & & 20 \\
\hline & & & & &
\end{tabular}

Feed toxicity mainly for aflatoxin for three rations of different types tested by ELISA method. In the present trial three experimental rations and feed ingredients taken for preparation of experimental ration-1 were found aflatoxin negative and below the toxic level.

\subsection{Housing and Management}

The chicks were housed in a clean well ventilated room, previously disinfected with formalin. Each group was presented by two replicate of 50 birds. The experimental house was divided into six pens of equal size by using bamboo materials and wire netting. The doors, windows, wire netting etc. of the house was painted before starting the experiment. Fresh dried rice husk litter was spread on the floor of the pens at a depth of about 0.04 meter before placing the chicks in the pens to maintain brooding temperature. The room was provided with electric heaters to adjust the environmental temperature and provide the light as per requirement. Each pen was equipped with two $100 \mathrm{~W}$ electric bulb suspended 0.4 meter above the litter. The feeder and drinker were fixed such a way that the birds could eat and drink conveniently The chicks were vaccinated against new castle disease vaccine and infectious bursal disease and provided with required veterinary care. Each groups of chicks received F-strain RD virus vaccine intra-ocularly at the dose rate of 0.05 $\mathrm{ml} / \mathrm{bird}$ on 5th day and IBD vaccine intra-ocularly at the dose rate of $0.05 \mathrm{ml} /$ bird at 14 days of age. Booster dose of $\mathrm{RD}$ vaccine F-strain was given on 21 days of age. The room was provided with electric heaters to adjust the environmental temperature and provide the light as per requirement.
Feeding of Birds: Chicks were reared from 1 day old to 42 days on the experimental diets and were allowed ad libitum access to feed and water throughout the study. On the first day the chicks were provided with only crushed maize and then given pre-starter diet along with drinking water. They were fed with pre-starter, starter, finisher ration on the day of assigning the treatment and the beginning of the starter period the required amount of broiler starter feed were procured. The same procedure was followed in the procurement of broiler grower and broiler finisher diets.

Meat samples of breast muscle were taken from carcass of each group with scissor and sharp knife and the samples were wrapped in a polythene bag and kept in deep fridge for proximate analysis of meat as outlined by AOAC [9].

\section{Methods}

\subsection{Crude Protein}

Nitrogen in the sample was determined by the Kjeldahl method and was multiplied by factors 6.25 to determine the crude protein content of the feed.

The representative sample of feed was first weighed and digested with concentrated $\mathrm{H}_{2} \mathrm{SO}_{4}$ in presence of 10 g anhydrous sodium sulphate and 0.5 g copper sulphate. Digested materials were dissolved in distilled water and collected in a $250 \mathrm{ml}$ volumetric flask. Then, known volume of aliquot was distilled after being made alkaline with $45 \%$ sodium hydroxide solution and the liberated ammonia was trapped in $2 \%$ boric acid solution. The same was titrated against N/10 $\mathrm{H}_{2} \mathrm{SO}_{4}$ (standard). Percentage of nitrogen was calculated by the following formula.

\% of Nitrogen

$=\frac{\text { Vol. of } \mathrm{N} / 10 \mathrm{H}_{2} \mathrm{SO}_{4} \text { used of } \times 0.0014 \times 250 \times 100}{\text { Vol. of aliquot taken }(\mathrm{ml}) \times \text { gm. of substance taken }}$

$\%$ of $\mathrm{CP}=\%$ of $\mathrm{N}_{2} \times 6.25$

\subsection{Experimental Design}

\begin{tabular}{|c|c|c|c|}
\hline Groups & Provided with & Divided into & $\begin{array}{l}\text { Provided ad } \\
\text { libitum Feed }\end{array}$ \\
\hline $\begin{array}{l}\text { Group } \\
\text { E1 }\end{array}$ & $\begin{array}{l}\text { Ration } 1 \text { prepared } \\
\text { with conventional } \\
\text { ingredients }\end{array}$ & $\begin{array}{l}\text { A } \\
\text { (50 broiler chick) } \\
\text { A2 } \\
\text { ( } 50 \text { broiler chick) }\end{array}$ & $\begin{array}{l}\text { a-pre starter }(0-7 d) \\
\text { b-starter }(8-28 d) \\
\text { c-finisher }(29-42 d)\end{array}$ \\
\hline $\begin{array}{l}\text { Group } \\
\text { E2 }\end{array}$ & $\begin{array}{l}\text { Ration } 2 \\
\text { procured from } \\
\text { market }\end{array}$ & $\begin{array}{l}\text { A1 } \\
\text { ( } 50 \text { broiler chick) } \\
\text { A2 } \\
\text { ( } 50 \text { broiler chick) }\end{array}$ & $\begin{array}{l}\text { a-pre starter }(0-7 d) \\
\text { b-starter }(8-28 d) \\
\text { c-finisher }(29-42 d)\end{array}$ \\
\hline $\begin{array}{l}\text { Group } \\
\text { E3 }\end{array}$ & $\begin{array}{l}\text { Ration } 3 \\
\text { procured from } \\
\text { market }\end{array}$ & $\begin{array}{l}\text { A1 } \\
\text { ( } 50 \text { broiler chick) } \\
\text { A2 } \\
\text { ( } 50 \text { broiler chick) }\end{array}$ & $\begin{array}{l}\text { a-pre-starter }(0-7 d) \\
\text { b-starter }(8-28 d) \\
\text { c-finisher }(29-42 d)\end{array}$ \\
\hline
\end{tabular}


Feeding trial was conducted for a period of 42 days, A1 and A2 were simply the replicas of E1, E2 and E3 respectively.

Crude Fats: The wet tissue was homogenized with a mixture of chloroform and methanol $(3: 1 \mathrm{v} / \mathrm{v})$ in such proportions that a miscible system was formed with the water in the tissue. Dilution with chloroform and water separates the homogenate into two layers, the chloroform layer containing all the lipids and the methanolic layer containing all the non-lipids. A purified lipid extract was obtained merely by isolating the chloroform layer [10] and weighed.

Element Analysis: Samples from the finisher feed E1 (Indigenous feed), E2 (Amrit) and E3 (Godrej) as well as from the breast muscle of the 42 days old chickens were considered for crude protein (CP) and elemental assessment. Breast muscles obtained from the chickens were kept in $10 \%$ formalin for $24 \mathrm{~h}$ and thereafter $4-5 \mathrm{~g}$ of them were subjected to acid digestion [11]. In brief, the weighed samples were added with $\mathrm{HNO}_{3}-\mathrm{HCLO}_{4}$ (3:1) acid digestion until a clear precipitation was obtained. The sample was diluted to $50 \mathrm{ml}$ with deionized water and subjected for element analysis in Atomic absorption spectrophotometer (Perkin-Elmer 3110) at SAIF, NEHU, Shillong, India. The content of $\mathrm{Na}$ and $\mathrm{K}$ was determined by the emission technique (acetylene air flame). The $\mathrm{P}$ was determined by colorimetric method [12]. The data collected were subjected to ANOVA followed by Fischer's test of significance.

\section{Results and Discussion}

The results of the present investigation have been depicted in the Table 4 and $\mathbf{5}$. Administration of feed as shown exerts clear impact on the breast muscle of 42 days broiler presenting distinct variation among the E1, E2 and E3. The source of protein for the indigenously prepared feed was the maize, groundnut and soyaben against the unknown composition of the two commercially available feed.

Table 4. Element (mg/kg) present in the indigenous feed (E1) and two commercially available feeds E2 (Amrit) and E3 (Godrej).

\begin{tabular}{cccc}
\hline & E1 & E2 & E3 \\
\hline $\mathrm{Ca}$ & $5.64 \pm 0.92^{\mathrm{a}}$ & $7.38 \pm 0.83$ & $8.42 \pm 0.72$ \\
$\mathrm{Mg}$ & $1.75 \pm 0.06$ & $1.22 \pm 0.42$ & $1.39 \pm 0.54$ \\
$\mathrm{P}$ & $5.24 \pm 0.39$ & $5.80 \pm 0.45$ & $6.34 \pm 0.24$ \\
$\mathrm{Na}$ & $1.05 \pm 0.03$ & $1.24 \pm 0.09$ & $0.94 \pm 0.33$ \\
$\mathrm{~K}$ & $8.44 \pm 0.42^{\mathrm{a}}$ & $9.12 \pm 0.36^{\mathrm{a}}$ & $5.42 \pm 0.11$ \\
$\mathrm{Fe}$ & $13.54 \pm 1.45$ & $9.39 \pm 2.45^{\mathrm{a}}$ & $1.9 \pm 2.34$ \\
$\mathrm{Cu}$ & $0.89 \pm 0.01^{\mathrm{a}}$ & $0.70 \pm 0.01$ & $0.92 \pm 0.01$ \\
$\mathrm{Zn}$ & $1.54 \pm 0.03^{\mathrm{a}}$ & $1.34 \pm 0.02$ & $0.82 \pm 0.01$ \\
$\mathrm{Mn}$ & $1.51 \pm 0.02^{\mathrm{a}}$ & $1.49 \pm 0.02^{\mathrm{a}}$ & $0.54 \pm 0.01$ \\
$\mathrm{Se}$ & $0.11 \pm 0.01^{\mathrm{a}}$ & $0.42 \pm 0.01$ & $0.32 \pm 0.02$ \\
\hline
\end{tabular}

Mean \pm SD, Superscript ${ }^{\text {a }}$ denotes significant difference.

Table 5. Evaluation of protein (g/kg), fats (g/kg) and elements in the breast muscle of male (M) and female (F) Broiler chicken fed with indigenous feed (E1), and two commercially available feed E2 (Amrit) and E3 (Godrej) for a period of 42 days.

\begin{tabular}{|c|c|c|c|c|c|c|}
\hline \multirow{2}{*}{ Para-meters } & \multicolumn{2}{|c|}{ E1 } & \multicolumn{2}{|c|}{ E2 } & \multicolumn{2}{|c|}{ E3 } \\
\hline & $\mathbf{M}$ & $\mathbf{F}$ & $\mathbf{M}$ & $\mathbf{F}$ & $\mathbf{M}$ & $\mathbf{F}$ \\
\hline Protein & $221.64 \pm 5.50$ & $210.0 \pm 3.9$ & $225 \pm 4.5$ & $231.2 \pm 3.98$ & $215.64 \pm 5.2$ & $240.0 \pm 4.2^{\mathrm{a}}$ \\
\hline Fats & $58.6 \pm 8.34$ & $80.0 \pm 9.3$ & $73.4 \pm 8.2$ & $70.1 \pm 6.42$ & $78.39 \pm 6.34$ & $105.5 \pm 6.9^{a}$ \\
\hline $\mathrm{Ca}$ & $33.24 \pm 7.2$ & $43.64 \pm 8.2$ & $42.30 \pm 5.9$ & $38.84 \pm 4.92$ & $32.64 \pm 6.23$ & $33.89 \pm 4.21$ \\
\hline $\mathrm{Mg}$ & $310.6 \pm 6.5$ & $354.0 \pm 7.2$ & $331.0 \pm 5.0$ & $350.3 \pm 3.9$ & $400.1 \pm 8.4$ & $450.4 \pm 5.4^{\mathrm{a}}$ \\
\hline $\mathrm{P}$ & $266.22 \pm 6.8$ & $411.4 \pm 6.2^{\mathrm{a}}$ & $299.2 \pm 4.5$ & $302.6 \pm 5.4$ & $322.2 \pm 5.6$ & $311.7 \pm 7.3$ \\
\hline $\mathrm{Mn}$ & $11.2 \pm 4.9$ & $11.3 \pm 2.4$ & $11.0 \pm 1.5$ & $11.6 \pm 3.4$ & $14.2 \pm 4.11$ & $11.82 \pm 3.42$ \\
\hline $\mathrm{Cu}$ & $10.90 \pm 3.3$ & $13.2 \pm 3.4$ & $11.5 \pm 1.61$ & $8.2 \pm 2.11$ & $16.5 \pm 2.21$ & $7.2 \pm 3.62$ \\
\hline $\mathrm{Zn}$ & $1.4 \pm 0.11$ & $1.5 \pm 0.4$ & $1.3 \pm 0.31$ & $1.5 \pm 0.31$ & $1.4 \pm 0.3$ & $2.9 \pm 0.41^{\mathrm{a}}$ \\
\hline Se & $1.1 \pm 0.07$ & $1.1 \pm 0.12$ & $1.2 \pm 0.20$ & $1.1 \pm 0.34$ & $1.5 \pm 0.31$ & $1.2 \pm 0.21$ \\
\hline $\mathrm{Na}$ & $115.4 \pm 5.92$ & $116.4 \pm 4.2$ & $118.4 \pm 3.9$ & $111.2 \pm 3.52$ & $115.7 \pm 2.7$ & $116.2 \pm 3.98$ \\
\hline $\mathrm{K}$ & $450.2 \pm 8.2^{\mathrm{a}}$ & $438.1 \pm 5.7^{\mathrm{a}}$ & $388.2 \pm 3.9$ & $411.11 \pm 4.2$ & $380.4 \pm 4.3$ & $375.2 \pm 3.84$ \\
\hline
\end{tabular}

Mean \pm SD, superscript (a) denotes significant difference. 
Elements contents present in the feed (E1) and commercially available feed E2 and E3 have been found to be consistent with the chicken growths. Indigenously prepared feed E1 was found to contain significantly lower Ca $(5.64 \mathrm{mg} / \mathrm{g})$ and Se $(0.11 \mathrm{mg} / \mathrm{g})$ as well as higher $\mathrm{Cu}(0.89 \mathrm{mg} / \mathrm{g}), \mathrm{Zn}(1.54 \mathrm{mg} / \mathrm{g})$ compared to the commercial feeds E2 and E3. As well, higher quantum of $\mathrm{K}, \mathrm{Fe}$ and $\mathrm{Mn}$ and relatively higher Se in E2 and E3 were assayed. Analysis of two other categories of feed viz pre-starter and starter feed either showed identical or no significant variation, hence not shown in the text. The higher quantity of $\mathrm{Ca}$ in the feed lowers the palatability and interfere with the utilization of $\mathrm{P}, \mathrm{Zn}, \mathrm{Mg}$ and $\mathrm{Mn}$, though its precise requirement is not known [13] The maximum requirement up to the level of finished meat has been stated as $\mathrm{Mn}, \mathrm{Zn}$, and Fe at $50 \mathrm{mg}$ [13] against the availability of these minerals at 1.51, 1.54 and 13.54 $\mathrm{mg} / \mathrm{kg}$ of finisher food of this investigation (Table 4).

Analysis of breast muscle after 42 day of feeding and that too with finisher demonstrated significantly higher value of crude protein $(240 \mathrm{~g} / \mathrm{kg})$ and fats $(105.5 \mathrm{mg} / \mathrm{kg})$ in the E3 feed female breast muscle against E2 (231.2 and $70.1 \mathrm{~g} / \mathrm{kg}$ proteins and fats respectively) and E1 (210.0 and $80.0 \mathrm{~g} / \mathrm{kg}$ proteins and fats respectively) feed. The quality of feature of the meat depends upon the protein and fats. The variation recorded in this investigation might be an attribution of the feed content and there has been insignificant variation of protein between E1 (Indigenous) and E2 (Amrit). However, less amount of fat accumulation could be noticed in male under the feeding of E1 while it is higher in E3 female, which might be related to the egg production. The higher quantum of protein $(22.26 \%)$ in the breast muscle of male and female and higher value of fats in female $(2.78 \%)$ in broiler chicken have already been highlighted [14]. Further a higher fat content in female broiler [15] and its difference is associated with the metabolic differences, higher competitiveness, and variation in fat deposition capabilities, nutritional requirement and higher hormonal influences [16]. The muscles are finer and tender in female and the female accumulate more fats compared to male [4]. Earlier, it was suggested low fat quantity in male abdomen [17]. In fact, breast muscle contain approximately $24 \%$ crude protein against $22 \%$ in broiler chicken [18], while it was recorded as $219 \mathrm{~g} / \mathrm{kg}$ of protein and $16.7 \mathrm{~g} / \mathrm{kg}$ of fats respectively in male and female broiler chicken [19].

The present finding is very much suggestive of the negative correlation between the fats and protein content and in conformity with the work of various workers $[19,20]$. However, it is true that the fat content in meat largely depends upon the factors like animal species, breed, gender and anatomic origin of the muscles. The important feature of broiler chicken meat from dietary aspects might be from dietetic aspects and excessive accumulation of fat lies in an imbalance between feed intake and consumption of energy [21]. The present feeding suggested higher quantum of protein in breast muscle in the finished product and it could reasonably be argued that the indigenously prepared feed might be considered for quality meat production.

Evaluation of elements analysis showed presence of higher Ca (43.64 mg/g) in the E1 fed female broiler, significantly different from that of E2 and E3 fed chicken breast muscles. However, the present findings could not support the data of some workers for Calcium [19]. This might be due to the difference in breed or strain, however, demands further characterization.

The Mg quantum in the breast muscle was evaluated and ranged between 310 to $450 \mathrm{mg} / \mathrm{g}$ of breast tissue and significantly higher Mg was noted in male and female E3 fed feed. The variation might, probably be due to the feed composition and notably the higher $\mathrm{Mg}$ is related to the cardiovascular disease [22]. Moreover, higher $\mathrm{Mg}$ in the diet has been linked to a 22\% lower risk of Ischemic heart disease [23]. Yet the breast muscle of the E1 and E2 group has had higher range of $\mathrm{Mg}$ against $130 \mathrm{mg} / \mathrm{g}$ in Ross 308 broiler chicken [19]

The macro element $\mathrm{P}$ was in higher direction in the range of 266 to $411 \mathrm{mg} / \mathrm{g}$, while the P in E1 fed female breast muscle showed significantly higher quantity $(\mathrm{P}<$ $0.01 ; 411 \mathrm{mg} / \mathrm{g}$ ). The possible reason might be due to the variation of feed intake and therefore, it is suggested that the male and female should distinctly be segregated. On the other hand, the importance of $\mathrm{P}$ in various activities have already been suggested and it was stated that $\mathrm{P}$ influences on the release of energy from protein, carbohydrate and fats while the body was exposed to stress bearing factors [24].

Trance quantities of minerals present in the tissue serve a variety of function in their bodies. The present findings for $\mathrm{Mn}$ and $\mathrm{Cu}$ showed their identical presence amongst the E1, E2 and E3 feed categories, while the Fe quantum of female fed with E1 feed depicted significantly higher values $(4.7 \mu \mathrm{g} / \mathrm{g})$ and the Se and $\mathrm{Zn}$ in E3 feed breast muscle exhibited higher values $(2.9 \mu \mathrm{g} / \mathrm{g})$. Significantly higher quantity of K was noted in male, fed with E1 feed. Presence of identical quantity of $\mathrm{Na}$ and Se was recorded amongst the three groups (Table 2). As mentioned elsewhere, Na, K, Zn, Cu, Mn, Se, Fe occurring tissue affects the osmotic balance in the body [25]. The median value of potassium in BBQ breast meat has been estimated at $284 \mathrm{mg} / 100 \mathrm{~g}$. The average amount of potassium in $100 \mathrm{~g}$ of chicken breast is $273.77 \mathrm{mg}$ against the $450.0 \mu \mathrm{g} / \mathrm{g}$ in the breast tissue fed with local 
feed E1 in this investigation. It is evident that $\mathrm{Cu}$ regulates cholesterol biosynthesis and the distribution of fatty acids in poultry [25]. The concentration of selenium (Se) in chicken breast meat in Scandinavia is, however, only about $0.01 \mathrm{mg} / 100 \mathrm{~g}$. Thigh meat from broilers raised on a feed supplemented with $40 \mathrm{~g}$ rapeseed oil, $10 \mathrm{~g}$ linseed oil per $\mathrm{kg}$ diet and $0.27,0.44,0.78$ or $1.16 \mathrm{mg}$ Se per $\mathrm{kg}$ diet could be described as a functional food. This broiler meat is a good contribution to a better strategy for increasing the food content of Se and very long chain omega-3 fatty acids [26]. Presence of optional quantum of elements in feed mixtures enable the proper functioning of an organism and good production performance [27] and thus the prepared feed E1 could be of ideal with that of the commercially available feeds.

\section{REFERENCES}

[1] V. Lazar, "Poultry-Raising," University of Agriculture in Brono, 1990, p. 210.

[2] Ingr, “Meat Technology,” Brono, 1996, p. 290.

[3] J. Michard, "Latest Trends in Feeding Modern Broilers," International Poultry Production, Vol. 18, No. 3, 2010, pp. 7-9.

[4] I. Ingr, "Evaluation of Animal Products," Brono, 1993, p. 180.

[5] Arbor Acres, "Broiler Management Guide," Aviagen, 2009, p. 18.

[6] T. Jayalakshmi, R. Kumararaj, T. Sivakumar and T. T. Vanan, "Carcass Characteristics of Commercial Broilers Reared under Varying Stocking," Tamilnadu Journal of Veterinary and Animal Sciences, Vol. 5, No. 4, 2009, pp. 132-135.

[7] B. O. Esonu, U. D. Ogbonna, G. A. Anyanwu, O. O. Emelanom, M. C. Uchegbu, E. B. Etuk and A. B. I. Udedibe, "Evaluation of Performance, Organ Characteristics and Economic Analysis of Broiler Finisher Fed Dried Rumen Digesta," International Journal of Poultry Science, Vol. 5, No. 12, 2006, pp. 1116-1118. http://dx.doi.org/10.3923/ijps.2006.1116.1118

[8] D. V. Reddy, "Applied Nutrition,” Oxford \& IBH Publishing Co. Pvt. Ltd, New Delhi, 2008, pp. 132-167.

[9] AOAC, “Official Methods of Analysis," 16th Edition, Association of Analytical Chemists, Washington DC, 2000.

[10] E. G. Bligh and W. J. Dyer, "A Rapid Method of Total Lipid Extraction and Purification," Canadian Journal of Biochemistry and Physiology, Vol. 37, No. 8, 1959, pp. 911-917. http://dx.doi.org/10.1139/059-099

[11] M. J. Khanke, “Analysis of Fish and Seafood Wet Digestion in Analytical Methods for Atomic Absorption Spectroscopy,” 1966, p. 197.

[12] D. W. Bolin and O. E. Stamberg, "Rapid Digestion Method for Determination of Phosphorus," Industrial and Engineering Chemistry, Analytical Edition, Vol. 16, No.

\section{5, 1944, p. 345. http://dx.doi.org/10.1021/i560129a031}

[13] M. L. Scott, M. C. Nesheim and R. J. Young, "Nutrition of the Chicken,” 2nd Edition, M.L. Scot \& Associates, Ithaca, 1975, p. 555.

[14] S. Bogosavljevic-Boskovic, S. Mitrovic, R. Djokovic, V. Doskovicand and V. Djermanovic, "Chemical Composition of Chicken Meat Produced in Extensive Indoor and Free Range Rearing Systems,” African Journal of Biotechnology, Vol. 9, No. 5, 2010, pp. 9069-9075.

[15] M. Snaz, A. Flore, P. Perez de Ayala and C. J. Lopezborte, "Effect of Fatty Acid Saturation in Broiler Diets on Abdominal Fat and Breast Muscle Fatty Acid Composition and Susceptibility Lipid Oxidation,” Poultry Science, Vol. 78, 1999, pp. 378-382.

[16] E. Tumova and A. Teimouri, "Fat Deposition in the Broiler Chicken: A Review," Scientia Agriculturae Bohemica, Vol. 41, No. 2, 2010, pp. 121-128.

[17] W. A. Backer, J. V. Spencer, L. W. Minoch and J. A. Vastrate, "Prediction of Fat and Fat Free Live Weight in Broiler Chicken Using, Backskin Fat, Abdominal Fat and Live Body Weight,” Poultry Science, Vol. 50, 1979, pp. 835-845. http://dx.doi.org/10.3382/ps.0580835

[18] J. Simeonovova, "Technology of Poultry, Eggs and Other Minor Animal Products,” MZLU Brno, 1999, p. 247.

[19] P. Suchy, P. Jelinek, E. Stakova and J. Hucl, “Chemical Composition of Muscles of Hybrid Broiler Chickens during Prolonged Feeding Czech,” Journal of Animal Sciences, Vol. 47, 2002, pp. 511-518.

[20] E. Matusovicova, "Technology of Poultry Production,” Priorda, Bratislava, 1986, p. 393.

[21] M. Skrivan, "Poultry Raising Agrospoj,” Praha, 2000, p. 203.

[22] J. Y. Shin, P. Xun, Y. Nakamura and K. He, "Egg Consumption in Relation to Risk of Cardiovascular Disease and Diabetes: A Systematic Review and Meta-Analysis," American Journal of Clinical Nutrition, Vol. 98, No. 1, 2013, pp. 146-159. http://dx.doi.org/10.3945/ajcn.112.051318

[23] W. Zhang, H. Iso, T. Ohira, C. Date and A. Tamakoshi, "Association of Dietary Magnesium Intake with Mortality from Cardiovascular Disease," Journal of Atherosclerosis, Vol. 221, No. 2, 2012, pp. 587-595. http://dx.doi.org/10.1016/j.atherosclerosis.2012.01.034

[24] A. Wojeik, T. Mituniewicz, K. Iwanczuk-Czernik, J. Sowinska, D. Witkowska and L. L. Chorazy, "Contents of Macro and Micro Elements in Blood Serum and Breast Muscle of Broiler Chickens Subjected to Different Variants of Pre-Slaughter Handling Czech,” Animal Sciences, Vol. 54, No. 4, 2009, pp. 175-181.

[25] R. I. Bakalli, G. M. Pesti, W. L. Regland and V. Konjufea, "Dietary Copper in Excess of Nutritional Requirement Reduces Plasma and Breast Muscle Cholesterol of Chickens,” Poultry Science, Vol. 74, No. 2, 1995, pp. 360-365. http://dx.doi.org/10.3382/ps.0740360

[26] A. Haug, O. A. Christophersen and T. Sogn, "Chicken Meat Rich in Selenium and Omega-3 Fatty Acids," The Open Agriculture Journal, Vol. 5, 2011, pp. 30-36. 
http://dx.doi.org/10.2174/1874331501105010030

[27] A. Gergely, M. Kontraszt, A. Herman, T. Acs, J. Gundel,

T. Palfy, S. Mihok and A. Lugasi, "Microelements in
Muscle Tissues of Turkeys Kept on Intensive and Extensive Farming Systems,” Proceedings on Trace elements in the Food Chain, Budapest, 2006, pp. 436-440. 